\title{
Effect of the drying method and texture improvers on reconstitution behavior of yogurt powder: physical and microbiological properties
}

\author{
Efecto del método de secado y mejoradores de textura \\ sobre el comportamiento de reconstitución de un yogurt en \\ polvo: propiedades físicas y microbiológicas
}

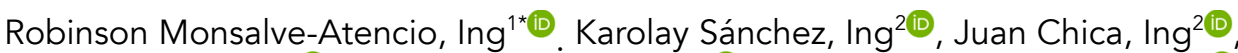
Jairo Camaño, Ing ${ }^{2(\mathbb{C}}$, Johana Saldarriaga Ing ${ }^{2(\mathbb{C}}$, Julian Quintero-Quiroz, PhD ${ }^{30}$

JOURNAL VITAE

School of Pharmaceutical and Food Sciences

ISSN 0121-4004 | ISSNe 2145-2660

University of Antioquia Medellin, Colombia

Filliations

${ }^{1}$ Grupo de Investigación Biotecnología de Alimentos BIOALI. Departamento de Alimentos, Facultad de Ciencias Farmacéuticas y Alimentarias, Universidad de Antioquia. Medellín

Colombia.

2 Departamento de Alimentos, Facultad de Ciencias Farmacéuticas y Alimentarias, Universidad de Antioquia. Calle 67 No. 53 - 108, Medellín

Colombia.

${ }^{3}$ Grupo Diseño y Formulación de Medicamentos, Cosméticos y

Afines - DYFOMECO. Facultad de Ciencias Farmacéuticas y Alimentarias, Universidad de Antioquia. Calle $67 \mathrm{No}$

$53-108$, Medellín, Colombia

*Corresponding Robinson Monsalve Atencio robinson.monsalve@udea.edu.co

Received: 16 January 2021 Accepted: 25 May 2021 Published: 11 June 2021

\section{ABSTRACT}

Background: One of the most used and effective preservation strategies in foods is drying. However, there are problems with the rheological properties, color, and viability of lactic acid bacteria in the yogurt once reconstituted when applying such conservation strategies. Objectives: Determine the concentration of the type of texture improver and drying that minimizes the negative effect on the rheological, color, and microbiological properties of a reconstituted yogurt powder. Methods: Intended to determine the texture improver which increases rheological properties of reconstituted yogurt powder, a mixture type experimental design was applied where three texture improvers were assessed; carboxymethylcellulose (CMC) (mass fraction 0 - 1), pectin (mass fraction 0 - 1), and xanthan gum (mass fraction 0 - 1 ). The rheological parameters; consistency index $(K)$, flow behavior $(n)$, viscosity at $100 s^{-1}(\eta)$, the storage $\left(G^{\prime}\right)$ and loss $\left(G^{\prime \prime}\right)$ modules, and the phase shift angle $(\delta)$ of each of the reconstitutions were considered as design-dependent variables. Secondly, a central composite design (facecentered) was used for assessing the effectiveness of the drying (convection, spray-drying, and freeze-drying), the concentration of the texture improver (0.0 - 1.0\%), and the yogurt powder concentration (8.0 - 15.0\%). The above-mentioned rheological parameters, color, and viability of the lactic acid bacteria from each reconstituted yogurt powder were considered as the dependent variables. Optimization sought to match the parameters of reconstituted yogurt powder that approximated the conditions of fresh yogurt. Results: The independent variables in their lineal expression and some interactions between them had statistically significant differences $(p<0.05)$. At a concentration of $10.59 \%$ with $0.03 \%$ xanthan gum, the reconstitution of freeze-dried yogurt powder was the optimized condition $(p<0.05)$ and obtained the rheological, color, and microbiological parameters closest to fresh yogurt. Conclusions: The drying of the yogurt by freeze-drying mixed with xanthan gum as a texture improver allowed to obtain a reconstituted yogurt with properties close to the fresh product for direct consumption.

Keywords: Yogurt powder, rheological properties, freeze-drying, spray-drying, texture improvers. 


\section{RESUMEN}

Antecedentes: Una de las estrategias de conservación más utilizadas y efectivas en los alimentos es el secado. Sin embargo, existen problemas en las propiedades reológicas, el color y la viabilidad de bacterias ácido lácticas en el yogur una vez reconstituido al aplicar tales estrategias de conservación. Objetivos: Determinar la concentración del tipo de mejorador de textura y secado que minimiza el efecto negativo sobre las propiedades reológicas, de color y microbiológicas de un yogur en polvo reconstituido. Métodos: Para determinar el mejorador de textura que aumente las propiedades reológicas del yogur en polvo reconstituido, se aplicó un diseño experimental de tipo de mezcla donde se evaluaron tres mejoradores de textura; carboximetilcelulosa (CMC) (fracción de masa 0 -1), pectina (fracción de masa 0 -1) y goma xantan (fracción de masa 0 -1); los parámetros reológicos: índice de consistencia (K), comportamiento de flujo (n), viscosidad a 100s ${ }^{-1}$ ( $\eta$ ), módulos de almacenamiento $\left(G^{\prime}\right)$ y pérdida $\left(G^{\prime \prime}\right)$, y ángulo de desfase $(\delta)$ de cada una de las reconstituciones fueron considerados como variables dependientes. En segundo lugar, se utilizó un diseño central compuesto (centrado a las caras) para evaluar el efecto del tipo de secado (convección, secado por aspersión y liofilización), la concentración del mejorador de textura (0.0 - $1.0 \%$ ) y concentración del yogur en polvo (8.0 - 15.0\%). Como variables dependientes se consideraron los parámetros reológicos mencionados anteriormente, el color y la viabilidad de las bacterias ácido lácticas de cada yogur en polvo reconstituido. La optimización buscó igualar los parámetros del yogur en polvo reconstituido que se aproximaran a las condiciones del yogur fresco. Resultados: Las variables independientes en su expresión lineal y algunas interacciones entre ellas tuvieron diferencias estadísticamente significativas $(p<0.05)$. La reconstitución de yogur liofilizado en polvo a una concentración de $10.59 \%$ con $0.03 \%$ de goma xantan, fueron las condiciones optimizadas $(p<0.05)$ que obtuvieron los parámetros reológicos, de color y microbiológicos más cercanos al yogur fresco. Conclusión: El secado del yogur por liofilización mezclado con goma xantan como mejorador de la textura, permitió obtener un yogur reconstituido con propiedades cercanas al producto fresco para consumo directo.

Palabras Clave: Yogur en polvo, propiedades reológicas, liofilización, atomización, mejoradores de textura.

\section{INTRODUCTION}

Yogurt is a hygienist dairy product obtained from the fermentation of lactic acid bacteria such as Streptococcus thermophilus and Lactobacillus bulgaricus. These microorganisms act on lactose from milk, the main carbohydrate, to obtain lactic acid resulting from the transformation (1). During the lactose to lactic acid transformation at average temperatures of $37^{\circ} \mathrm{C}$, the increase in milk acids and the ongoing and extensive heat treatment make the milk's proteins change their structure. This situation allows new interactions between proteins and forming the gel structure characteristic of those types of products and their sensory characteristics (2). Per capita consumption of yogurt has grown about $10 \%$ in the last five years due to its high nutritional value and the positive effect on consumers' health, making yogurt one of the fermented foods most consumed and popular (1). Conservation technologies propose drying methods such as freeze-drying, spray-drying, and convective drying, where the main goal is to remove water to preserve the product stably. These drying methods efficiently reduce water activity $\left(a_{w}\right)$ through dehydration, and when applied to yogurt, make it a high-quality product without refrigeration needed $(3,4)$. The main intention of the production of yogurt powder refers to the application at the industrial level -providing nutrients and characteristic flavors- which facilitates its storage and transport, increasing its shelf life and easy incorporation to other formulations (4). However, it is notable that obtaining yogurt powder for direct consumption requires improvement because, depending on the technique and drying conditions, there are structural changes during the dehydration of yogurt. This causes significant differences in the rheological behavior and viability of lactic acid bacteria of the products compared to fresh yogurt. Thus, decreasing the potential benefits for consumer health and acceptance of the final product $(5,6)$.

The physical, physicochemical, and microbiological properties of yogurt powder by different methodologies such as spray-drying, freezedrying, and convective drying $(3,7-9)$ have been studied. However, no reports compare the effects of these methodologies on the quality properties of the reconstituted product. This research aim was to evaluate the effect of three drying methods (convective drying, spray-drying, and freeze-drying) and the use of texture improvers on the rheological, color, and viability parameters of lactic acid bacteria of a reconstituted yogurt powder, seeking to obtain properties close to fresh product properties.

\section{MATERIALS AND METHODS}

\subsection{Materials}

The reactants, boric acid, hydrochloric acid, sulfuric acid, methylene blue, copper sulfate heptahydrate, methyl red, methylene blue, sulfate, potassium hydroxide, sodium hydroxide, and petroleum ether, 
were of analytical grade. Xanthan gum was feed grade and Bellchem brand. The nonfat Pasco brand yogurt was obtained from a supermarket in Medellín (Colombia). For comparison, a commercial yogurt powder was purchased from the local market. The fresh yogurt was characterized by moisture ( 90\%), total solids $(\sim 10.0 \%)$, protein $(\sim 5.5 \%)$, and lipids $(\sim 1.5 \%)$ content according to the AOAC (Association of Official Analytical Chemists) (AOAC, 1995). The protein content was determined by the Kjeldahl method $(\mathrm{N} \times$ 6.25) (AOAC 2011.04). The moisture content was evaluated by a gravimetric method heating the sample at $120^{\circ} \mathrm{C}$ until reaching constant weight (AOAC 934.06). Ash content was determined by calcination in an oven at $550{ }^{\circ} \mathrm{C}$ until reaching stable weight (AOAC 942.05). The lipid content was determined by Soxhlet extraction with ether (AOAC 922.06).

\subsection{Yogurt drying process}

Different yogurt samples were dried by three methods, spray-drying, freeze-drying, and convective drying. Once each yogurt sample was dried, they were milled using a Kinematica Polymix ${ }^{\circledR}$ analytical mill (PX-MFC 90D, Bohemia, NY, USA) and sifted into an ASTME E11 sieve (Fisher Scientific Company, ASTM E-11 Standard, EE. UU) with a mesh number 80 , less than $500 \mu \mathrm{m}$.

\subsubsection{Convective drying}

The yogurt was spread on a tray with a thickness of $\sim 0.5 \mathrm{~cm}$ and then dried in an industrial convection oven (Unox Domenica XF043, Italy) at a temperature of $50{ }^{\circ} \mathrm{C}$ until it reached equilibrium moisture (7).

\subsubsection{Spray-drying}

The yogurt was dried into a Mini Spray Dryer B-290 (Büchi, Suiza). The sample was fed at $0.54 \mathrm{~L} / \mathrm{h}$ flow rate at $15{ }^{\circ} \mathrm{C}$, with inlet/outlet temperatures of $171 / 60^{\circ} \mathrm{C}$, respectively. Atomization pressure of 296 $\mathrm{KPa}$ and $1.54 \mathrm{~m}^{3} / \mathrm{min}$ flow rate (5).

\subsubsection{Freeze-drying}

Yogurt samples were frozen in trays approximately $\sim 0.5 \mathrm{~cm}$ thick and freeze-dried in a lyophilizer (Centricol, Medellín, Colombia) at $\sim 31 \mathrm{~Pa}$ pressure and a sublimation temperature of $25^{\circ} \mathrm{C}$ (11).

The yogurt powder from each drying process was stored in freezing at $-20^{\circ} \mathrm{C}$ using container materials with high moisture barrier until use.

\subsection{Reconstitution of the yogurt powder}

\subsubsection{Optimization of the type of texture improver}

A mixture-type experimental design was applied to determine the mixture or type of texture improver that increases the rheological properties of reconstituted yogurt powder. Three texture improvers were used: CMC (mass fraction between 0 - 1), pectin (mass fraction between 0 - 1), and xanthan gum (mass fraction between 0 - 1). As constant variables, it was determined to reconstitute freeze-dried yogurt powder used as a model in water at a concentration of $10.0 \% \mathrm{w} / \mathrm{v}$, using a concentration of $1.0 \% \mathrm{w} / \mathrm{v}$ of the texture improver or mixture of texture improvers, and the samples were reconstituted at stirring of $150 \mathrm{rpm}$ for 2 minutes. The rheological parameters (consistency index $(K)$, flow behavior $(n)$, viscosity at $100 \mathrm{~s}^{-1}(\eta)$, storage $\left(G^{\prime}\right)$ and loss $\left(G^{\prime \prime}\right)$ modules, and phase shift angle

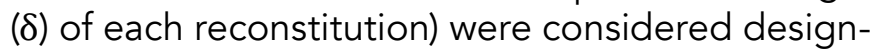
dependent variables. From these conditions, 13 experimental runs were evaluated, which are shown in Table 1.

2.3.2 Optimization procedures for: drying method, the concentration of texture improver, and yogurt powder for reconstitution

A central composite design (face-centered) was proposed to determine the reconstitution conditions of yogurt powder approaching the rheological, color parameters, and viability of lactic acid bacteria of the fresh yogurt, using the Design Expert Software ${ }^{\circledR}$ (Version 8.0.6, Stat-Ease, USA). Three independent variables were studied, method for drying (spray-drying, freeze-drying, and convective drying), texture improver concentration (0.0 - 0.5 - $1.0 \% \mathrm{w} / \mathrm{v})$, and yogurt powder concentration in the reconstitution process $(8.0-11.5-15.0 \% \mathrm{w} / \mathrm{v})$, thus obtaining 33 experimental runs which are presented in a randomized pattern in Table 4. As dependent variables, the rheological parameters: K, $n, \eta, G^{\prime}, G^{\prime \prime}$, and $\delta$ were studied. The optimization of the experimental design was determined by approximating the dependent variables measured to those obtained in the measurements made in fresh yogurt. The relative and absolute errors were calculated between the responses predicted by the model versus the ones obtained experimentally under optimal conditions. Additionally, the color and viability of lactic acid bacteria for each dry powder were evaluated. 


\subsection{Determination of rheological parameters}

Rheological evaluations were conducted on a rheometer (Anton Paar MCR92, Graz, Austria) employing plate-cone with $1^{\circ}$ as geometry (CP501). For the determination of the consistency index $(K)$, flow behavior $(n)$, and the viscosity at $100 \mathrm{~s}^{-1}(\eta)$ parameters were determined by applying Herschel Bulkley's model in the data obtained from the flow curve of each sample. The flow curve was measured as a function of shear rate in three stages $\left(4^{\circ} \mathrm{C}\right)$, an upward stage $\left(0.01-100 \mathrm{~s}^{-1}\right)$ with $60 \mathrm{~s}$ duration, a shear rate constant $\left(100 \mathrm{~s}^{-1}\right)$ for another $60 \mathrm{~s}$, and a downward stage $\left(100-0.01 \mathrm{~s}^{-1}\right)$ with the same duration (12). The storage module $\left(G^{\prime}\right)$ (defined as the elastic fraction), the loss module $\left(G^{\prime \prime}\right)$ (used to determine the viscous fraction), and the phase shift angle $(\delta)$ (that describes a tendency toward more fluid-like behavior (dilute solution), consistent fluidlike behavior (concentrated solution) or consistent solid-like behavior (like gel) of the samples) were determined in a frequency sweeps in the linear viscoelastic region (LVR). LVR was evaluated at a constant angular frequency (1 rad/s) and shear strain ranging from 0.001 to $100 \%$ once the LVR was calculated for each sample. Frequency sweeps were performed by varying the angular frequency from 10 to $0.1 \mathrm{rad} / \mathrm{s}$ at a constant temperature of $4{ }^{\circ} \mathrm{C}$ and a continuous shear strain determined by $\operatorname{LVR}(13,14)$.

\subsection{Color measurement}

The color analysis was performed using a highQuality colorimeter-spectrometer (NR200, Shenzhen $3 \mathrm{NH}$ Co., China) that allowed to obtain the parameters $L^{*}\left(L=0\right.$ - black to $L=100$ - white), $a^{*}(-a=$ green to $+a=$ red) and $b^{*}(-b=$ blue to $+b=$ yellow), $c^{*}$ (Chroma coordinates) and $h^{\circ}$ (hue angle). $\Delta E^{\star}$ numerically represents the perception of the color difference for the human eye between two food samples, which was calculated using equation $\Delta E^{\star}$ $=\left(\left(\Delta L^{\star}\right)^{2}+\left(\Delta a^{\star}\right)^{2}+\left(\Delta b^{\star}\right)^{2}\right)^{1 / 2}$ (15). $\Delta E^{\star}$ was calculated from each dry yogurt reconstituted compared with yogurt fresh.

\subsection{Lactic acid bacteria count}

The total lactic acid bacteria (LAB) count was performed on De Man Agar, Rogosa, and Sharpe Agar (MRS) plates according to Norma Técnica Colombiana (NTC) 5034 of 2002 (16). The samples were deeply sown in triplicate and incubated at 37 ${ }^{\circ} \mathrm{C}$ for 48 hours.

\subsection{Statistical analysis}

Data variability was conducted by analysis of variance (ANOVA), the test for comparison of means using the LSD (least significant difference), and the Fisher's test. The Statgraphics centurion XVIII statistical tool was used.

\section{RESULTS}

\subsection{Optimization of the type of texture improver}

The results of the rheological parameters of the reconstituted yogurt dried by freeze-drying, which was used as a model to evaluate the effect of the addition of texture improvers, can be seen in Table 1 .

Table 1. The experimental matrix evaluated for the reconstitution of the yogurt powders ${ }^{a}$.

\begin{tabular}{|l|l|l|c|c|c|c|c|c|}
\hline CMC (A) & Pectin (B) & Xanthan gum $(\mathbf{C})$ & $\mathbf{n}$ & $\mathbf{K}$ & $\begin{array}{c}\mathbf{n} \\
{[\mathbf{m P a} \cdot \mathbf{s}]}\end{array}$ & $\begin{array}{c}\mathbf{G}^{\prime} \\
{[\mathbf{P a}]}\end{array}$ & $\begin{array}{c}\mathbf{G} \\
{[\mathbf{P a}]}\end{array}$ & $\begin{array}{c}\boldsymbol{\delta} \\
{[\mathbf{R a d}]}\end{array}$ \\
\hline 100.00 & 0.00 & 0.00 & 0.27 & 21.58 & 166.91 & 1167.50 & 380.80 & 0.32 \\
\hline 66.67 & 16.67 & 16.67 & 0.27 & 22.94 & 974.34 & 688.72 & 229.22 & 0.32 \\
\hline 50.00 & 50.00 & 0.00 & 0.32 & 16.23 & 854.83 & 400.03 & 134.54 & 0.32 \\
\hline 0.00 & 0.00 & 100.00 & 0.24 & 35.71 & 1293.10 & 868.81 & 301.57 & 0.33 \\
\hline 100.00 & 0.00 & 0.00 & 0.31 & 16.55 & 844.10 & 469.13 & 156.49 & 0.32 \\
\hline 0.00 & 50.00 & 50.00 & 0.25 & 36.51 & 1437.80 & 973.69 & 337.38 & 0.33 \\
\hline 33.33 & 33.33 & 33.33 & 0.24 & 33.53 & 1252.80 & 671.52 & 222.03 & 0.32 \\
\hline 16.67 & 66.67 & 16.67 & 0.25 & 30.23 & 1149.70 & 1001.60 & 339.63 & 0.33 \\
\hline 0.00 & 100.00 & 0.00 & 0.28 & 15.40 & 737.13 & 519.76 & 175.07 & 0.32 \\
\hline 0.00 & 100.00 & 0.00 & 0.26 & 17.58 & 806.19 & 1598.80 & 508.70 & 0.31 \\
\hline 16.67 & 16.67 & 66.67 & 0.24 & 36.19 & 1359.70 & 582.81 & 202.48 & 0.33 \\
\hline 50.00 & 0.00 & 50.00 & 0.25 & 34.45 & 1335.00 & 497.60 & 178.72 & 0.34 \\
\hline 0.00 & 0.00 & 100.00 & 0.22 & 45.29 & 1429.40 & 1226.50 & 414.46 & 0.33 \\
\hline
\end{tabular}

a Data are median. K: consistency index. n: flow behavior. $\eta$ : dynamic viscosity to $100 \mathrm{~s}^{-1}$. G': storage module to 10 Rad/s. $\mathrm{G}^{\prime \prime}$ : loss modules to 10 Rad/s. $\delta$ : phase shift angle. 
Table 1 shows a variation in the reconstituted yogurt's rheological parameters according to the texture improver used. The analysis of variance (ANOVA) of the design (Table 2) determined that the interaction between the three texture improvers had statistically significant differences $(p<0.05)$ for all viscosity-related parameters under study. Notably, the use of xanthan gum as a texture improver in the max mass fraction was the condition that allows achieving the maximum increase in the viscosity of reconstituted yogurt powder (Fig. 1a). In turn, this modifies the consistency index of the solution by increasing molecular physical interactions while remaining fluid with a shear thinning behavior.

Table 2. ANOVA table for the response variables for the evaluation of the texture improver.

\begin{tabular}{|l|c|c|c|c|c|c|}
\hline \multirow{2}{*}{ Variable } & $\mathbf{n}$ & $\mathbf{K}$ & $\boldsymbol{\eta}[\mathbf{m P a} \cdot \mathbf{s}]$ & $\mathbf{G}^{\prime}[\mathbf{P a}]$ & $\mathbf{G}{ }^{\prime}[\mathbf{P a}]$ & $\boldsymbol{\delta}$ \\
\cline { 2 - 7 } & $\mathbf{p}$-value & $\mathbf{p}$-value & $\mathbf{p}$-value & p-value & p-value & p-value \\
\hline Model & 0.003 & 0.002 & 0.001 & 0.030 & 0.032 & 0.102 \\
\hline Linear mixing & 0.003 & 0.002 & 0.002 & 0.105 & 0.110 & 0.102 \\
\hline AB & ----- & ----- & 0.518 & 0.011 & 0.011 & ----- \\
\hline AC & ----- & ----- & 0.046 & 0.032 & 0.032 & ----- \\
\hline BC & ----- & ----- & 0.009 & 0.144 & 0.183 & ----- \\
\hline Lack of Fit & 0.661 & 0.503 & 0.922 & ----- & ----- & ----- \\
\hline r2 & 0.685 & 0.811 & 0.935 & 0.913 & 0.911 & 0.479 \\
\hline r2-adj & 0.622 & 0.773 & 0.889 & 0.805 & 0.800 & 0.330 \\
\hline
\end{tabular}

A: CMC; B: pectin; C: xanthan gum. K: consistency index, $n$ : flow behavior, $\eta$ : dynamic viscosity to $100 \mathrm{~s}^{-1}, \mathrm{G}^{\prime}$ : storage module to 10 Rad/s, $\mathrm{G}^{\prime \prime}$ : loss modules to 10 $\mathrm{Rad} / \mathrm{s}, \delta$ : phase shift angle.

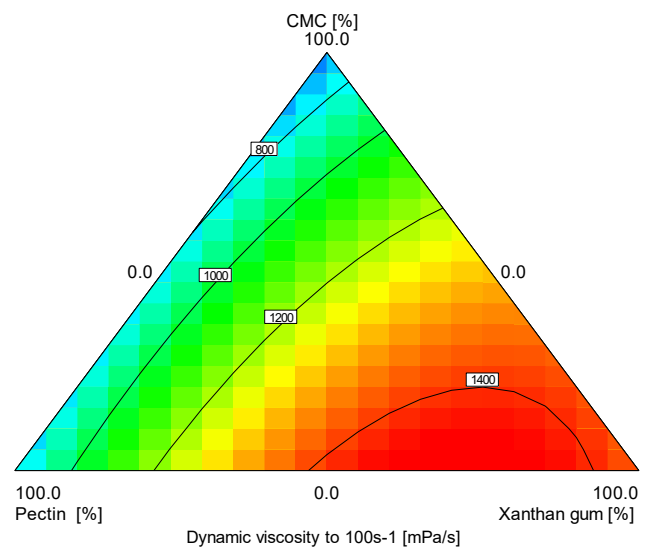

(a)

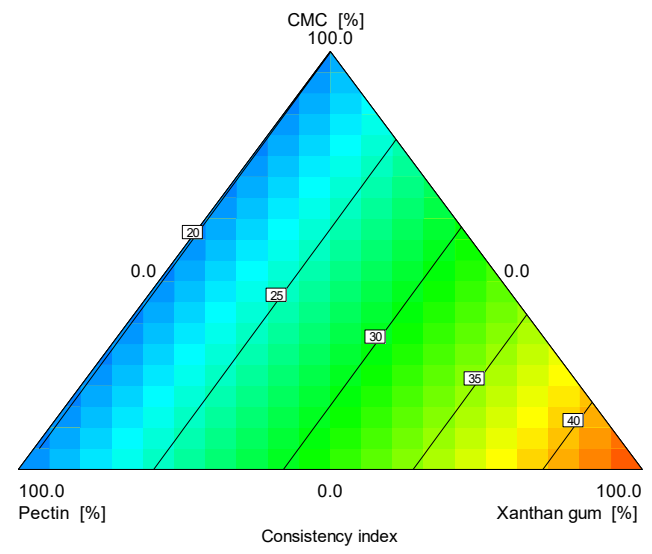

(b)

Fig. 1. Response surface plots for the significant effects of texture improvers: (a) dynamic viscosity to $100 \mathrm{~s}^{-1}$ ( $)$; (b) consistency index (K).

Alternatively, Table 2 shows that the viscoelastic parameters were not statistically significant. All the models were subjected to an optimization process looking for the mixture or texture improver that approximates fresh yogurt's rheological parameters.
Once the dependent variables were optimized, the estimated conditions for all rheological parameters of the reconstituted yogurt dried along with their relative error are listed in Table 3. 
Table 3. Predicted local maximum in the optimization for the texture improver.

\begin{tabular}{|c|c|c|c|c|c|c|c|c|c|}
\hline Parameter & $\begin{array}{c}\mathrm{CMC} \\
{[\%]}\end{array}$ & $\begin{array}{l}\text { Pectin } \\
{[\%]}\end{array}$ & $\begin{array}{c}\text { xanthan gum } \\
{[\%]}\end{array}$ & $\mathbf{n}$ & K & $\begin{array}{c}\eta \\
{[\mathrm{mPa} \cdot \mathrm{s}]}\end{array}$ & $\mathbf{G}^{\prime}[\mathrm{Pa}]$ & $\mathrm{G}^{\prime \prime}[\mathrm{Pa}]$ & $\delta$ \\
\hline Predicted & 0.0 & 0.0 & 100.0 & 0.2 & 43.8 & 1359.8 & 888,3 & 309,1 & 0,3 \\
\hline Experimental & 0.0 & 0.0 & 100.0 & 0.2 & 50.4 & 1659.4 & 1027,0 & 351,0 & 0,3 \\
\hline \multicolumn{4}{|l|}{ Relative error } & 0.0 & -6.6 & -299.6 & -138.7 & -41.9 & 0.0 \\
\hline \multicolumn{4}{|c|}{ Absolute error [\%] } & 2.6 & -15.0 & -22.0 & -15.6 & -13.5 & 1.2 \\
\hline
\end{tabular}

$\mathrm{K}$ : consistency index, $\mathrm{n}$ : flow behavior, $\eta$ : dynamic viscosity to $100 \mathrm{~s}^{-1}, \mathrm{G}^{\prime}$ : storage module to $10 \mathrm{Rad} / \mathrm{s}, \mathrm{G}^{\prime \prime}$ : loss modules to 10 Rad/s, $\delta$ : phase shift angle.

The absolute error compares the results predicted by the optimized model to the experimental ones obtained under optimal conditions. The absolute bias for the $K, \eta, G^{\prime}$, and $G^{\prime \prime}$ were highs and negatives. Thus, the experimental results obtained were more significant than those predicted by the models. For the cases of $\mathrm{n}$ and $\delta$, the absolute errors were less than $10 \%$, which indicates that the models obtained predict the behavior of rheological parameters.

\subsection{Evaluation of the drying method and concentration of the texture improver}

\subsubsection{Rheological properties}

For the 33 experimental runs, the flow curves and frequency sweep were constructed, adjusting the flow curves' results to Herschel Bulkley's model $\left(r^{2}>0.90\right)$. Experimental results were tabulated, and they are described in Table 4.

Table 4. The experimental matrix for the drying method and concentrations of the texture improver in the reconstituted yogurt ${ }^{a}$.

\begin{tabular}{|c|c|c|c|c|c|c|c|c|}
\hline $\begin{array}{c}\text { Yogurt powder } \\
{[\%]}\end{array}$ & $\begin{array}{l}\text { Texture improver } \\
{[\%]}\end{array}$ & Drying & $\mathbf{n}$ & K & $\stackrel{\eta}{\eta \mathrm{mPa} \cdot \mathrm{s}]}$ & $\begin{array}{c}\mathbf{G}^{\prime} \\
{[\mathrm{Pa}]}\end{array}$ & $\begin{array}{l}\text { G" } \\
{[\mathrm{Pa}]}\end{array}$ & $\delta$ [Rad] \\
\hline 11.5 & 0.5 & Convection & 0.3 & 5.7 & 222.7 & 491.9 & 158.2 & 0.3 \\
\hline 15.0 & 1.0 & Freeze-drying & 0.3 & 28.3 & 1001.2 & 499.2 & 140.6 & 0.3 \\
\hline 15.0 & 1.0 & Spray-drying & 0.2 & 12.5 & 404.8 & 197.1 & 53.3 & 0.3 \\
\hline 8.0 & 0.0 & Spray-drying & 0.7 & 0.1 & 10.5 & 5.9 & 0.5 & 0.3 \\
\hline 11.5 & 0.5 & Freeze- drying & 0.3 & 9.6 & 334.3 & 119.4 & 37.0 & 0.3 \\
\hline 11.5 & 0.5 & Spray-drying & 0.3 & 6.5 & 238.8 & 81.3 & 23.3 & 0.3 \\
\hline 11.5 & 0.0 & Freeze- drying & 0.2 & 14.1 & 453.5 & 463.3 & 133.6 & 0.3 \\
\hline 11.5 & 0.5 & Spray- drying & 0.3 & 5.3 & 223.1 & 60.4 & 19.4 & 0.3 \\
\hline 15.0 & 0.0 & Spray-drying & 0.7 & 0.0 & 11.9 & 0.4 & 0.2 & 0.5 \\
\hline 8.0 & 0.0 & Freeze- drying & 0.4 & 0.5 & 34.0 & 2.9 & 1.5 & 0.5 \\
\hline 15.0 & 0.0 & Convection & 0.3 & 5.3 & 237.0 & 218.3 & 65.5 & 0.3 \\
\hline 11.5 & 0.0 & Convection & 0.0 & 85.5 & 1104.8 & 2875.8 & 273.0 & 0.1 \\
\hline 8.0 & 0.5 & Convection & 0.2 & 10.2 & 326.2 & 124.4 & 37.5 & 0.3 \\
\hline 15.0 & 0.5 & Spray-drying & 0.3 & 10.2 & 416.1 & 243.6 & 66.9 & 0.3 \\
\hline 15.0 & 1.0 & Convection & 0.2 & 26.2 & 761.1 & 3377.3 & 1128.6 & 0.3 \\
\hline 8.0 & 0.5 & Spray- drying & 0.2 & 5.7 & 201.0 & 50.8 & 16.3 & 0.3 \\
\hline 15.0 & 0.5 & Freeze- drying & 0.3 & 13.7 & 571.2 & 244.9 & 76.6 & 0.3 \\
\hline 11.5 & 1.0 & Convection & 0.2 & 23.3 & 647.2 & 1487.3 & 482.9 & 0.3 \\
\hline 15.0 & 0.0 & Freeze- drying & 0.2 & 13.2 & 480.3 & 406.7 & 121.6 & 0.3 \\
\hline 8.0 & 0.5 & Freeze- drying & 0.2 & 5.9 & 197.6 & 47.0 & 14.5 & 0.3 \\
\hline
\end{tabular}




\begin{tabular}{|l|l|l|l|l|l|l|l|l|}
\hline $\begin{array}{c}\text { Yogurt powder } \\
{[\%]}\end{array}$ & $\begin{array}{c}\text { Texture improver } \\
{[\%]}\end{array}$ & \multicolumn{1}{|c|}{ Drying } & $\mathbf{n}$ & $\mathbf{K}$ & $\begin{array}{c}\mathbf{n} \\
{[\mathbf{m P a} \cdot \mathbf{s}]}\end{array}$ & $\begin{array}{c}\mathbf{G} \\
{[\mathbf{P a}]}\end{array}$ & $\begin{array}{c}\mathbf{G} \\
{[\mathbf{P a}]}\end{array}$ & $\boldsymbol{\delta}[\mathbf{R a d}]$ \\
\hline 11.5 & 0.0 & Spray- drying & 0.7 & 0.0 & 7.4 & 1.6 & 0.6 & 0.4 \\
\hline 8.0 & 1.0 & Freeze- drying & 0.2 & 15.5 & 426.3 & 119.6 & 27.8 & 0.2 \\
\hline 8.0 & 0.0 & Convection & 0.5 & 0.1 & 12.9 & 1.8 & 1.0 & 0.5 \\
\hline 11.5 & 0.5 & Convection & 0.3 & 6.8 & 245.0 & 2037.5 & 633.6 & 0.3 \\
\hline 11.5 & 1.0 & Spray- drying & 0.2 & 19.7 & 555.5 & 164.0 & 43.0 & 0.3 \\
\hline 11.5 & 0.5 & Convection & 0.3 & 9.3 & 368.5 & 344.2 & 109.1 & 0.3 \\
\hline 11.5 & 0.5 & Freeze- drying & 0.3 & 6.4 & 237.1 & 121.9 & 39.1 & 0.3 \\
\hline 11.5 & 0.5 & Spray- drying & 0.3 & 8.9 & 325.2 & 362.6 & 100.5 & 0.3 \\
\hline 15.0 & 0.5 & Convection & 0.2 & 15.5 & 538.0 & 1047.4 & 337.1 & 0.3 \\
\hline 11.5 & 0.5 & Freeze- drying & 0.3 & 11.5 & 413.2 & 237.6 & 71.7 & 0.3 \\
\hline 8.0 & 1.0 & Spray- drying & 0.2 & 14.7 & 408.3 & 103.9 & 23.8 & 0.2 \\
\hline 11.5 & 1.0 & Freeze- drying & 0.2 & 19.1 & 564.5 & 194.1 & 51.0 & 0.3 \\
\hline 8.0 & 1.0 & Convection & 0.2 & 25.9 & 641.9 & 629.1 & 211.7 & 0.3 \\
\hline
\end{tabular}

a Data are median. K: consistency index. n: flow behavior. $\eta$ : dynamic viscosity to $100 \mathrm{~s}^{-1}$. G': storage module to 10 Rad/s. G": loss modules to 10 Rad/s. $\delta$ : phase shift angle.

The study of the influence of the drying method, the concentration of yogurt powder, and the use of xanthan gum as a texture improver on the reconstitution of yogurt powder demonstrated a significant effect $(p<0.05)$ on rheological parameters. Table 4 shows how the drying methods effect generates differences in the reconstituted yogurt's viscosity and storage module, obtaining a higher viscosity for the reconstituted freeze-dried without using the texture improver and a greater storage module for the reconstituted spray-dried in the same condition. In the following way, a significant effect was observed between the results obtained using the texture improver compared to the samples without its use.

All the models were subjected to an optimization process, seeking to match the parameters studied to those obtained for the fresh yogurt. The response surface plots obtained from the experimental design analysis are shown in Fig. 2. The response surface plots show how the incorporation of the texture improvers and the change in the yogurt powder's concentration increase the viscosity of the reconstituted yogurt, and decrease the angle of phase change.

Fig. 2.a. shows how increasing the texture improver in the formulation of freeze-dried yogurt reconstitution is directly proportional with its dynamic viscosity. However, the greatest augments in dynamic viscosity occur when the texture improver and yogurt powder concentration were reconstituted at the highest concentration studied. This behavior is the same for all other types of drying (Fig. 2.c and 2.e), being less marked in convection-dried yogurt (Fig. 2.e). 


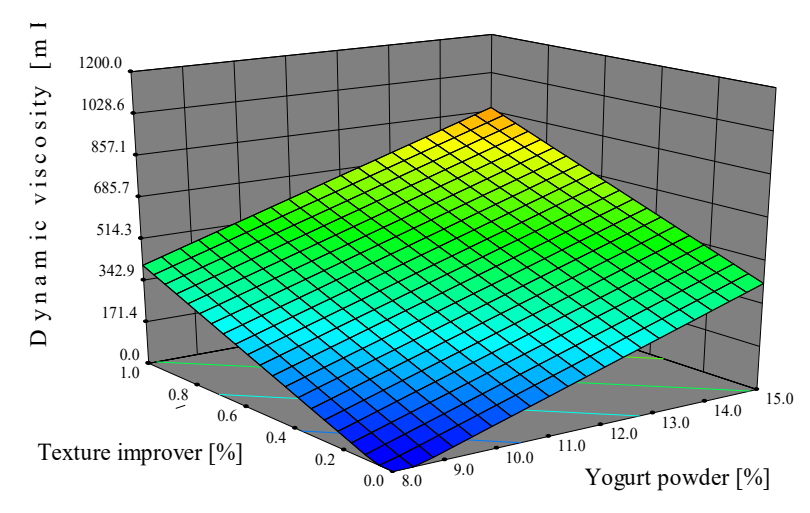

(a)

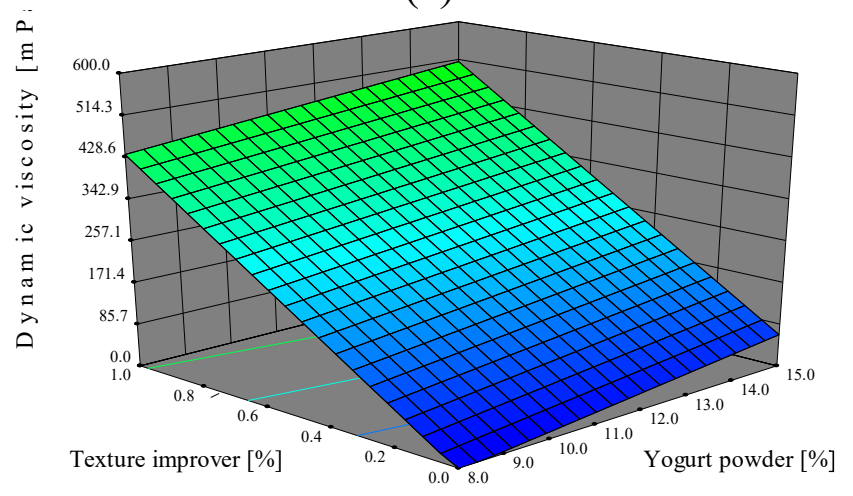

(c)

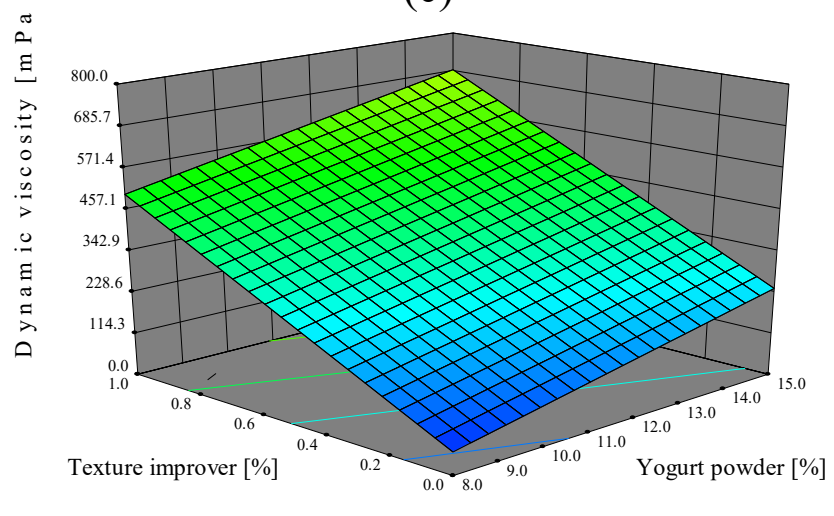

(e)

(e)

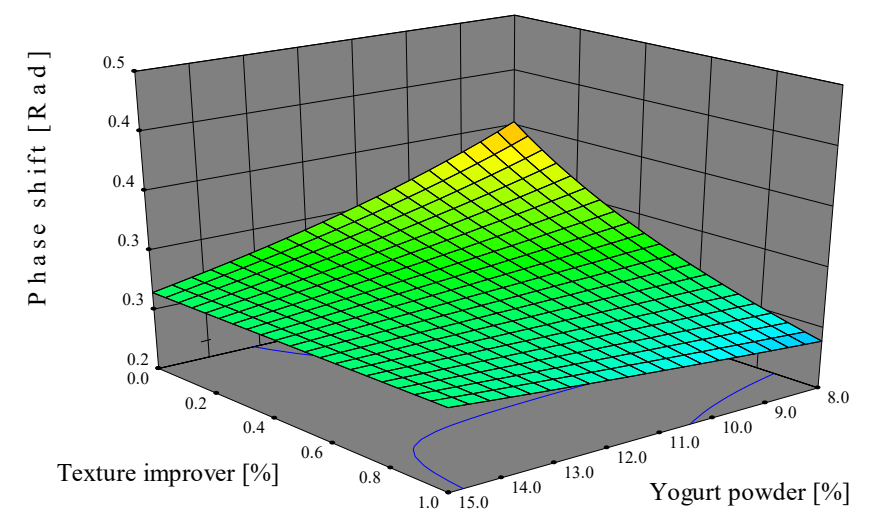

(b)

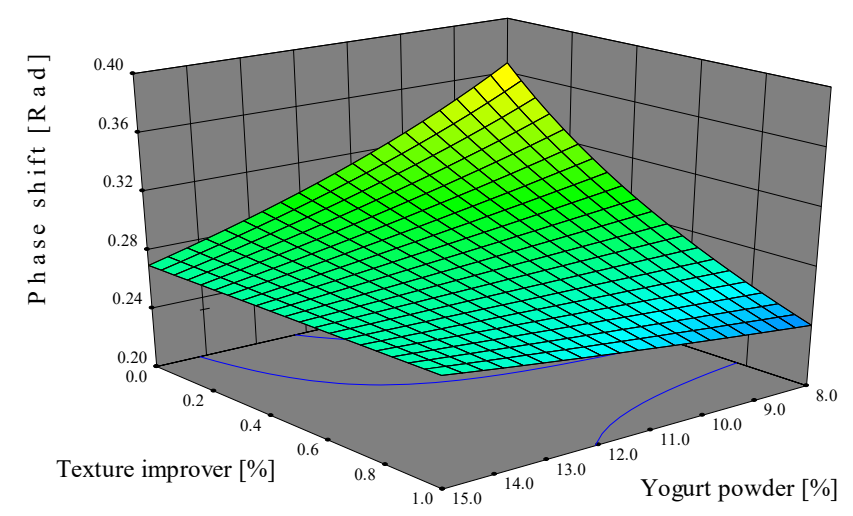

(d)

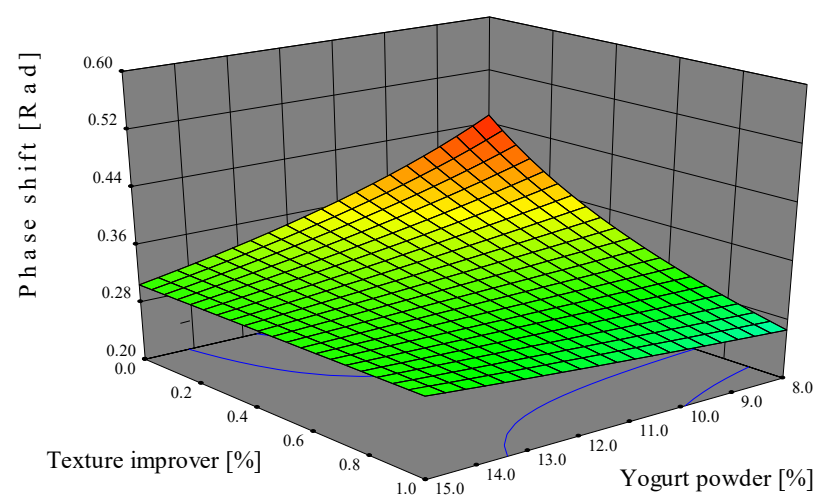

(f)

Fig. 2. Response surface plots for the significant effects of yogurt powder vs texture improver: (a) dynamic viscosity to $100 \mathrm{~s}^{-1}$ for freeze-drying, (b) phase shift angle for freeze-drying, (c) dynamic viscosity to $100 \mathrm{~s}^{-1}$ for spray-drying, (d) phase shift angle for spraydrying, (e) dynamic viscosity to $100 \mathrm{~s}^{-1}$ for dry for convection, and (f) phase shift angle for dry for convection.

This variability is confirmed by the ANOVA table (Table 5), demonstrating that all independent variables had a significant effect $(p<0.05)$ on most rheological parameters, except for the increase in yogurt concentration on the flow behavior index (n), which classify all reconstituted into shear thinning behavior fluids. 
Table 5. ANOVA Table for the response variables for the reconstitution of the yogurt powder.

\begin{tabular}{|c|c|c|c|c|c|c|}
\hline \multirow{2}{*}{ Variable } & $\mathbf{n}$ & $\mathbf{K}$ & $\eta[\mathrm{mPa} \cdot \mathrm{s}]$ & $\mathbf{G}^{\prime}[\mathrm{Pa}]$ & G" $[\mathrm{Pa}]$ & $\delta$ [Rad] \\
\hline & p-value & p-value & p-value & p-value & p-value & p-value \\
\hline Model & $<0.0001$ & $<0.0001$ & $<0.0001$ & $<0.0001$ & $<0.0001$ & $<0.0001$ \\
\hline A-yogurt powder [\%] & -------- & 0.002 & $<0.0001$ & 0.008 & 0.009 & 0.226 \\
\hline B-texture improver [\%] & $<0.0001$ & $<0.0001$ & $<0.0001$ & 0.0124 & 0.0122 & $<0.0001$ \\
\hline C-drying & 0.002 & 0.002 & 0.002 & 0.003 & 0.001 & 0.005 \\
\hline$A B$ & ------- & ------- & ------- & ------- & ------- & 0.001 \\
\hline$A C$ & -------- & 0.020 & 0.008 & 0.049 & 0.041 & -------- \\
\hline $\mathrm{BC}$ & $<0.0001$ & 0.025 & -------- & 0.004 & 0.002 & -------- \\
\hline$B^{2}$ & 0.005 & 0.003 & ------- & ------- & ------ & ------ \\
\hline Lack of fit & $<0.0001$ & 0.130 & 0.178 & 0.916 & 0.866 & 0.055 \\
\hline$r^{2}$ & 0.791 & 0.895 & 0.843 & 0.730 & 0.740 & 0.699 \\
\hline$r^{2}$-adj & 0.741 & 0.852 & 0.806 & 0.636 & 0.650 & 0.638 \\
\hline
\end{tabular}

$\mathrm{K}$ : consistency index, $\mathrm{n}$ : flow behavior, $\eta$ : dynamic viscosity to $100 \mathrm{~s}^{-1}, \mathrm{G}^{\prime}$ : storage module to $10 \mathrm{Rad} / \mathrm{s}, \mathrm{G}^{\prime \prime}$ : loss modules to 10 Rad/s, $\delta$ : phase shift angle.

Optimized variables, estimated conditions, and experimental results with relative and absolute errors are listed in Table 6 and Fig. 3. The optimal drying and reconstitution conditions for obtaining a reconstituted yogurt powder with waxy rheological parameters similar to fresh yogurt were $10.59 \%$ freeze-dried yogurt powder and $0.03 \%$ xanthan gum. These conditions allowed us to obtain parameters of dynamic viscosity, phase shift angle, and flow consistency index without statistically significant differences compared to fresh yogurt characteristics.

Table 6. Predicted local maximum in the optimization for the reconstitution of the yogurt powder.

\begin{tabular}{|c|c|c|c|c|c|c|c|c|c|}
\hline Parameter & $\begin{array}{l}\text { Yogurt pow- } \\
\text { der [\%] }\end{array}$ & $\begin{array}{c}\text { Texture } \\
\text { improver } \\
{[\%]}\end{array}$ & Drying & $\mathbf{n}$ & K & $\underset{[\mathrm{mPa} \cdot \mathrm{s}]}{\eta}$ & $\begin{array}{c}\mathbf{G}^{-} \\
{[\mathrm{Pa}]}\end{array}$ & $\begin{array}{l}\mathrm{G}^{\prime \prime} \\
{[\mathrm{Pa}]}\end{array}$ & $\delta$ [Rad] \\
\hline Predicted & 10.59 & 0.03 & Freeze-dry & 0.28 & 6.77 & 160.0 & 888.3 & 309.1 & 0.3 \\
\hline Experimental & 10.59 & 0.03 & Freeze-dry & $0.22^{\mathrm{a}}$ & $8.21^{\mathrm{a}}$ & $153.9^{\mathrm{a}}$ & $1027.0^{\mathrm{a}}$ & $351.0^{\mathrm{a}}$ & $0.3^{\mathrm{a}}$ \\
\hline \multicolumn{4}{|l|}{ Yogurt } & $0.28^{\mathrm{a}}$ & $2.65^{b}$ & $160.8^{\mathrm{a}}$ & $35.5^{\mathrm{b}}$ & $10.2^{b}$ & $0.3^{\mathrm{a}}$ \\
\hline \multicolumn{4}{|l|}{ Relative error } & 0.1 & -1.4 & 6.1 & 106.7 & 33.5 & 0.1 \\
\hline \multicolumn{4}{|c|}{ Absolute error [\%] } & 22.8 & -21.3 & -3.96 & 56.1 & 57.8 & 13.1 \\
\hline
\end{tabular}

Values are expressed as mean $(n=3)$. Different letters indicate statistically significant differences $(p<0.05)$. K: consistency index, $n$ : flow behavior, $\eta$ : dynamic viscosity to $100 \mathrm{~s}^{-1}, \mathrm{G}^{\prime}$ : storage module to $10 \mathrm{Rad} / \mathrm{s}, \mathrm{G}^{\prime \prime}$ : loss modules to $10 \mathrm{Rad} / \mathrm{s}, \delta$ : phase shift angle.

Fig. 3 shows that the reconstituted yogurt powder's flow curves and frequency sweeps under the optimized conditions and demonstrate a rheological behavior closer to fresh yogurt than commercial yogurt powder purchased from the local market. 


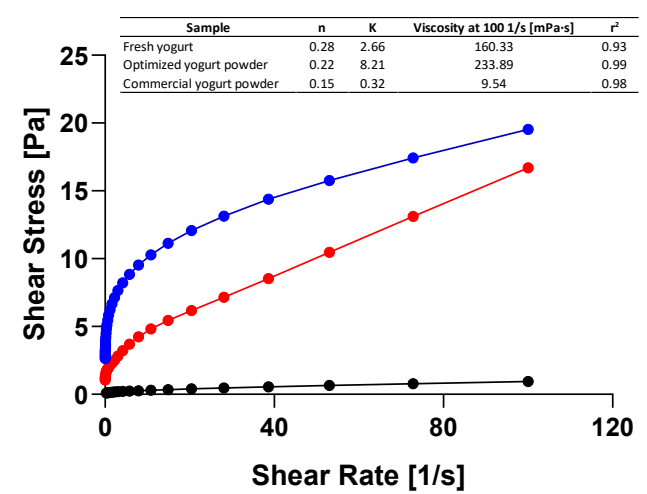

(a)

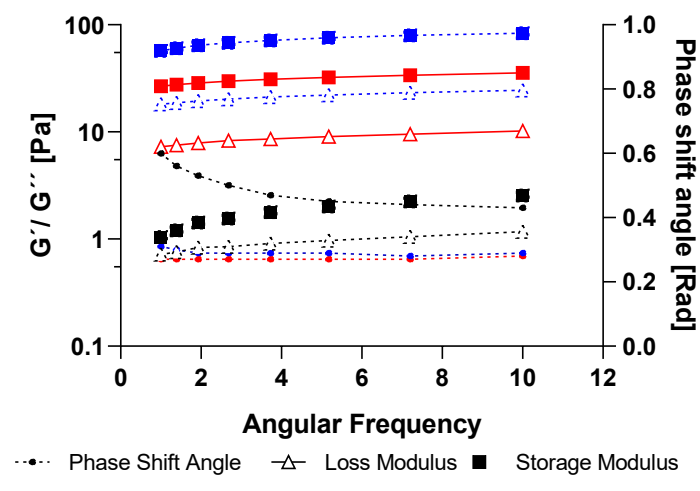

(b)

Fig. 3. Rheological tests of: (a) flow curve and (b) frequency sweep. Freeze-dried yogurt powder (blue), fresh yogurt (red), commercial yogurt powder (black). G': storage module (square), G': loss modules (triangle).

\subsection{Color and survival of lactic acid bacteria}

Once the parameters of freeze-dried yogurt powder have been optimized, the survival of lactic acid bacteria for the drying methods (convection, freeze-drying, and spray-drying), commercial yogurt powder, and fresh yogurt were $0,6.0 \times 10^{5}$, $1.0 \times 10^{4}, 0$, and $7.8 \times 10^{12}$ colony-forming units (CFU) $\cdot \mathrm{g}^{-1}$, respectively. The freeze-drying method allowed us to obtain the lowest log reduction cycles (7) of lactic acid bacteria, thus demonstrating the best survival rate. In contrast, convection drying and commercial yogurt powder showed an absence of $L A B$.

The color change quantification is reported in Fig 4, where the freeze-drying method does not significantly affect color parameters concerning fresh yogurt, despite reporting a value $\Delta E^{\star}$ higher than 2.5. Furthermore, it is observed that reconstituted freeze-dried yogurt presented higher $(p<0.05)$ color parameters than reconstituted commercial yogurt powder, showing greater $(p<$ 0.05) lightness (whiter).

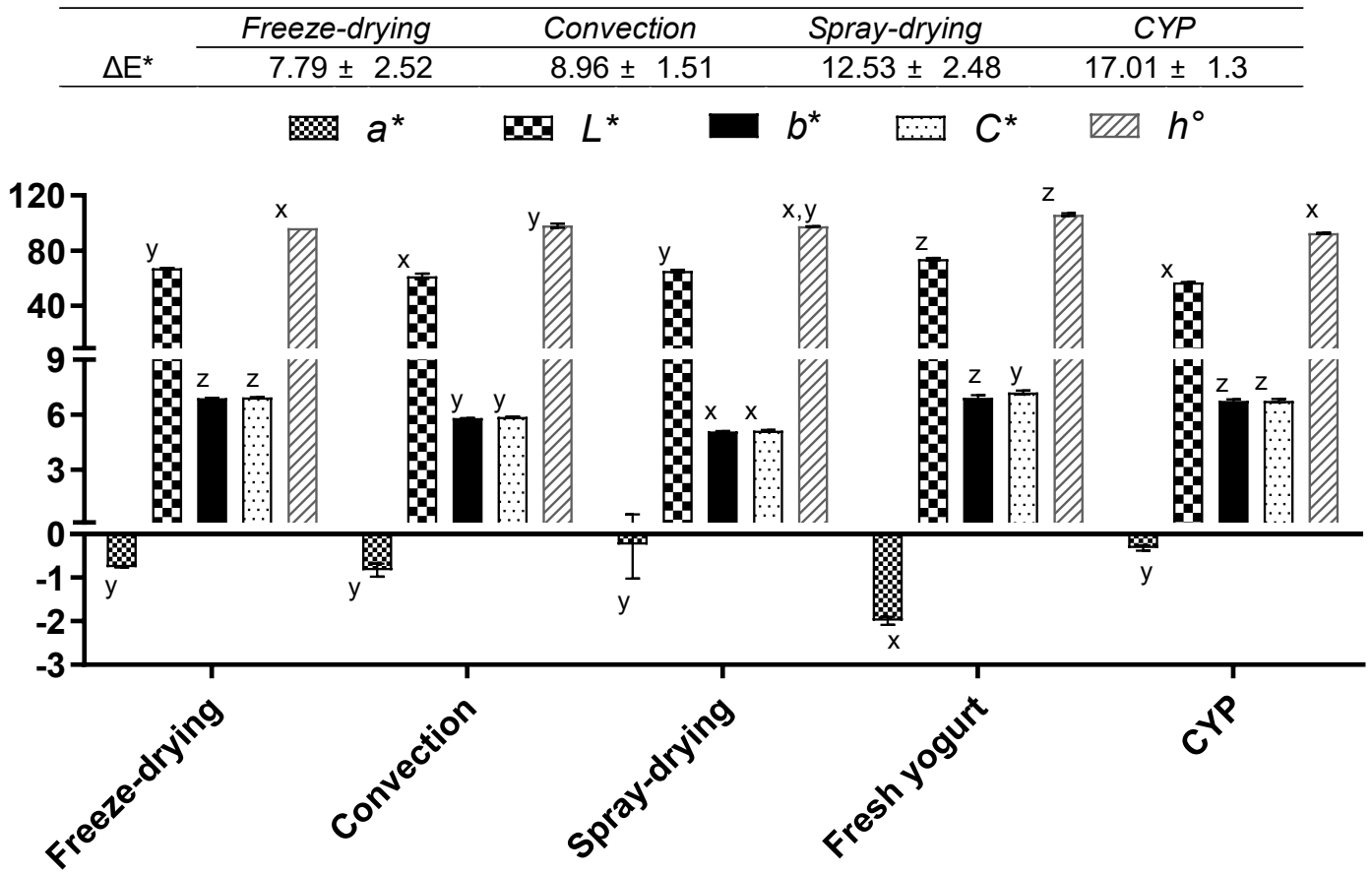

Fig. 4. Color of reconstituted powdered yogurts: fresh, commercial yogurt powder (CYP), and obtained by different drying methods. Values are expressed as mean \pm standard deviation $(n=3)$. Different letters $(x, y$, or $z)$ between the same parameter indicate statistically significant differences $(p<0.05)$. 


\section{DISCUSSION}

\subsection{Rheological properties}

Links between the protein-microstructure and rheology have been indicated (17) an in situ method for direct localization is required. The aim of this study was to investigate the specificity and stability of the monoclonal pectin antibody JIM7, anticarrageenan polyclonal antibody and the lectins wheat germ agglutinin (WGA). The influence of drying treatments on the reconstituted rheological properties is mainly attributed to the effect generated on the gel structure of the yogurt's proteins. High heat treatments on yogurt's proteins cause irreversible denaturation of the proteins, affecting the gel's three-dimensional structure, and this effect is reflected in the physical properties of yogurt powder. Carvalho et al. (2017) (18) evaluated the physical properties of a freeze-dried yogurt compared to a convectiondried yogurt. They determined that convection drying leads to a more compact structure, which produces a harder, crunchier dry product. At the same time, freeze-drying maintains a very aerated structure and, therefore, the final texture is softer and soaked. These differences in powder structure affect the rheological characteristics of reconstituted yogurt, as it is a harder and more compact powder, the dilution times are longer, and the gel structure generated by the yogurt's viscosity does not recover (19).

The results of this research reported that freezedried yogurt showed better rheological behavior than spray-dried. These results are related to reports made by Venir et al. (2007) (11), who obtained a freeze-dried yogurt powder and found that although its original strength was not sustained, its viscoelastic properties were retained. Similarly, Ramirez-Figueroa et al. (2002) (20) and SakinYilmazer et al. (2014) (21) affirmed that rheological characteristics of yogurt are lost during the spraydrying process, which represents a disadvantage in the water holding capacity together with a weakening in the rheological properties when the yogurt powder was reconstituted. This effect is attributed to the denaturation of proteins and destruction of the protein network at high outlet temperatures of spray-drying. The high shear rate of the spray-drying process also causes protein denaturation and destroys the weak gel structure of yogurt $(20,22)$.
Authors such as Song et al. (2014) (19) obtained a spray-dried yogurt powder and evaluated the dynamic viscosity of reconstitution yogurt. They determined that one strategy to achieve a reconstituted yogurt with a viscosity close to the original yogurt was obtained by increasing the concentration of yogurt powder in reconstitution. Similarly, Venir et al. (2007) (11) produced a freezedried yogurt powder modulating the amount of water in the reconstitution to recover the original strength. These results support the obtained outcomes in this research. By modifying the yogurt powder concentration in the reconstituted sample, also the rheological properties studied were modified. However, employing the increased concentration of yogurt powder in reconstitution was not an economically viable strategy, making the incorporation of texture improvers a better alternative. Although it is known that spray-drying disrupts the hydrocolloid polymeric network, causing drastic changes in the microstructure of the gel matrix (23), it is also well known that the addition of texture improvers such as hydrocolloids help prevent the serum expulsion from the yogurt (24), thus providing a solution to quality problems. Texture improvers have also been used to obtain crispy dehydrated snacks from dried yogurt by freeze-drying and air from foams structured using hydrocolloids (18). CMC can favor the gel network formation with casein (25). In the same way, pectin adsorbs via electrostatic interactions between carboxylate groups from pectin and cationic amino acids residues from casein in diluted acidified milk systems providing a stabilizing effect (26). However, studies have shown that additions of CMC and pectin, either alone or in combination, can stabilize acidified dairy drinks (25). In this research, the texture improver that showed the best rheological behavior corresponded to xanthan gum, which could be because xanthan gum can interact with milk protein in the yogurt gel network to increase viscosity, $G^{\prime}$ and $G^{\prime \prime}$ considerably (27). Nguyen et al. (2017) (28) found that adding xanthan gum improved the viscosity and gel strength of low-fat pot-set yogurt at a low dosage.

In the current study, it was notable that in general, the storage module was higher than the loss module, and the phase shift angle less than 0.7 (Table 4), indicating that the reconstituted yogurts behaved like a gel, showing a more elastic and recoverable deformation than viscous (27). Similar results are reported by Venir et al. (2007) (11) when measuring the storage 
and loss module of reconstituted freeze-dried yogurt. It was also necessary to reconstitute only $70 \%$ of the initial moisture to retain the original mechanical strength. Similar behavior to the results of this research was indicated by Sanz et al. (2008) (29) for the fiber-enriched yogurts; they could also adjust the shear stress- shear rate curves to the Herschel - Bulkley model, in this case, over the 0.1 $100 \mathrm{~s}^{-1}$ shear rate range. Rascón-Díaz et al. (2012) (23) also found a decrease in viscosity for a reconstituted spray-dried yogurt. They attributed the reduction in viscosity and shear peak in the flow curves of the reconstituted yogurts to the alteration of their microstructure by the spray-drying process.

\subsection{Color and survival of lactic acid bacteria}

A change in the color of dried yogurt powder is undesirable because it affects the consumer acceptance of the dried products (5). Color changes are attributed to Maillard's reactions between protein (casein) and yogurt lactose, with decreased water activity during drying, leading to a more brown surface and toasted flavor notes in reconstituted $(6,30,31)$. In this study, freeze-dried yogurt was the one that presented minor differences in color parameters compared to fresh yogurt according to the $\Delta E^{\star}$ value. Similar differences in color properties of freeze-dried and hot air-dried yogurt samples were also reported by Carvalho et al. (2017) (18). They concluded that even though freezedried yogurt had a matrix and water activity similar to air-dried yogurt, freeze-drying is conducted at freezing temperatures, which does not favor the development of this cascade of reactions. Similarly, another research reported that a higher drying temperature caused lower $L^{*}$ in yogurt powder produced by spray-drying (32). The main reason is presumably due to the more intense development of non-enzymatic browning reactions due to higher temperatures during the drying process $(18,33)$. However, although freeze-dried yogurt does not present statistically significant differences in some of the color parameters compared to fresh yogurt, the $\Delta E^{\star}$ value is greater than 2.5. This indicates that the consumer of reconstituted freeze-dried yogurt would notice a sensory difference concerning color between both samples.

The decrease in bacteria's survival rate is attributed to damage to nucleic acids, ribosomes, lipids, membranes, and proteins of microorganisms given by the stress induced by temperature change, phase changes, and drying $(6,30)$. In the current research, freeze-dried yogurts presented the lowest logarithmic reduction cycles for $B A L$, results similar to those reported by Tontul et al. (2018) (34), who found that the counts of $S$. thermophilus in all yogurt powders produced by refractance window drying were found to be lower than yogurt powders produced by freeze-drying. The mentioned authors obtained up to 5.73 LAB logarithmic reduction cycles in dry yogurts per refractance window.

\section{CONCLUSION}

Drying methods, yogurt powder concentration, and texture improvers have shown significant effects on the rheological, color, and microbiological properties of yogurt powder. Xanthan gum was the texture improver with the greater effect, reaching the highest viscosity when used in its max mass fraction. The result indicates that the obtained models can be useful to predict the behavior of rheological parameters of reconstituted yogurt powder. Highlighting that using $10.59 \%$ freeze-dried yogurt powder and $0.03 \%$ xanthan gum, the reconstituted yogurt powder presents similar dynamic viscosity parameters, phase shift angle, and flow consistency index to fresh yogurt. Overall, this study suggests that yogurt powders' quality and acceptability could be improved by the freeze-drying method and the xanthan gum. The mentioned conditions allowed to reach rheological parameters similar to fresh yogurt. Also, we obtained the lowest log reduction cycles of lactic acid bacteria and less color loss, which are of interest to consumers.

\section{ACKNOWLEDGEMENTS}

This work was sponsored by resources of the University of Antioquia, school of Pharmaceutical and Food Sciences. Also, special thanks to the research groups of Coloides and Grupo Diseño y Formulación de Medicamentos, Cosméticos y Afines for supporting the research with technical support and equipment loans.

\section{AUTHORS' CONTRIBUTIONS}

All authors participated equally in the development and writing of this research.

\section{DECLARATION OF COMPETING INTEREST}

The authors declare that they have no conflict of interest. 


\section{REFERENCES}

1. Remeuf F, Mohammed S, Sodini I, Tissier JP. Preliminary observations on the effects of milk fortification and heating on microstructure and physical properties of stirred yogurt. Int Dairy J. 2003;13(9):773-82. doi: https://doi.org/10.1016/S09586946(03)00092-X

2. Lee WJ, Lucey JA. Formation and physical properties of yogurt. Asian-Australasian J Anim Sci. 2010;23(9):1127-36. doi: https:// doi.org/10.5713/ajas.2010.r.05

3. Kennas A, Amellal-Chibane H, Kessal F, Halladj F. Effect of pomegranate peel and honey fortification on physicochemical, physical, microbiological and antioxidant properties of yoghurt powder. J Saudi Soc Agric Sci. 2020;19(1):99-108. doi: https://doi. org/10.1016/j.jssas.2018.07.001

4. de Medeiros ACL, Thomazini M, Urbano A, Correia RTP, FavaroTrindade CS. Structural characterisation and cell viability of a spray dried probiotic yoghurt produced with goats' milk and Bifidobacterium animalis subsp. lactis (BI-07). Int Dairy J. 2014;39(1):71-7. doi: https://doi.org/10.1016/j.idairyj.2014.05.008

5. Koc B, Yilmazer MS, Balkır P, Ertekin FK. Spray drying of yogurt: Optimization of process conditions for improving viability and other quality attributes. Dry Technol. 2010;28(4):495-507. doi: https://doi.org/10.1080/07373931003613809

6. Anal AK, Singh H. Recent advances in microencapsulation of probiotics for industrial applications and targeted delivery. Trends Food Sci Technol. 2007, 18(5):240-51. doi: https://doi. org/10.1016/j.tifs.2007.01.004

7. Hayaloglu AA, Karabulut I, Alpaslan M, Kelbaliyev G. Mathematical modeling of drying characteristics of strained yoghurt in a convective type tray-dryer. J Food Eng. 2007;78(1):109-17. doi: https://doi.org/10.1016/j.jfoodeng.2005.09.006

8. Santos GD, Nogueira RI, Rosenthal A. Powdered yoghurt produced by spray drying and freeze drying: A review. Brazilian J Food Technol. 2018;21:e2016127. doi: http://dx.doi.org/10.1590/19816723.12716

9. Seth D, Mishra HN, Deka SC. Functional and reconstitution properties of spray-dried sweetened yogurt powder as influenced by processing conditions. Int J Food Prop. 2017;20(7):1603-11. doi: https://doi.org/10.1080/10942912.2016.1214965

10. (AOAC) ASFTAM 15․ AMERICAN SOCIETY FOR TESTING AND MATERIALS (AOAC). 1998. doi: https://doi.org/10.1038/203565aO

11. Venir E, Del Torre M, Stecchini ML, Maltini E, Di Nardo P. Preparation of freeze-dried yoghurt as a space food. J food Eng. 2007;80(2):402-407. doi: https://doi.org/10.1016/j. jfoodeng.2006.02.030

12. $M u B, X u H, L i W, X u L$, Yang Y. Spinnability and rheological properties of globular soy protein solution. Food Hydrocoll. 2019;90:443-51. doi: https://doi.org/10.1016/j.foodhyd.2018.12.049

13. Caillard R, Remondetto GE, Mateescu MA, Subirade M Characterization of amino cross-linked soy protein hydrogels. J Food Sci. 2008;73(5):283-91. doi: https://doi.org/10.1111/j.17503841.2008.00780.x

14. Steffe JF. Rheological methods in food process engineering. Freeman press. 1996. 317-339 p.

15. Ramirez-Navas JS, Rodriguez de Stouvenel A. Characterization of Colombian quesillo cheese by spectrocolorimetry. Vitae. 2012;19(2):178-85

16. NTC5034. Microbiología de Alimentos y Alimentos para animales Método Horizontal para el recuento de Bacterias mesofílicas de ácido láctico. Técnica de recuento de colonias a $30^{\circ} \mathrm{C}$. Bogotá:
Instituto Colombiano de Normas Técnicas y de Certificación (ICONTEC); 2002.

17. Arltoft D, Madsen F, Ipsen R. Screening of probes for specific localisation of polysaccharides. Food Hydrocoll. 2007;21(7):106271. doi: https://doi.org/10.1016/j.foodhyd.2006.07.020

18. Carvalho MJ, Perez-Palacios T, Ruiz-Carrascal J. Physico-chemical and sensory characteristics of freeze-dried and air-dehydrated yogurt foam. LWT. 2017;80:328-34. doi: https://doi.org/10.1016/j. Iwt.2017.02.039

19. Song L, Aryana K. Reconstituted yogurt from yogurt cultured milk powder mix has better overall characteristics than reconstituted yogurt from commercial yogurt powder. J Dairy Sci. 2014;97(10):6007-15. doi: https://doi.org/10.3168/jds.2014-8181

20. Ramirez-Figueroa E, Salgado-Cervantes MA, Rodriguez GC, Garcia HS. Addition of hydrocolloids to improve the functionality of spray dried yoghurt. Milchwissenschaft. 2002;57(2):87-9.

21. Sakin-Yilmazer M, Koç B, Balkir P, Kaymak-Ertekin F. Rheological behavior of reconstituted yoghurt powder-An optimization study. Powder Technol. 2014;266:433-9. doi: https://doi.org/10.1016/j. powtec.2014.06.060

22. Kumar P, Mishra HN. Yoghurt Powder-A Review of Process Technology, Storage and Utilization. Food Bioprod Process. 2004;82(2):133-42. doi: https://doi.org/10.1205/0960308041614918

23. Rascón-Díaz MP, Tejero JM, Mendoza-Garcia PG, García HS, Salgado-Cervantes MA. Spray Drying Yogurt Incorporating Hydrocolloids: Structural Analysis, Acetaldehyde Content, Viable Bacteria, and Rheological Properties. Food Bioprocess Technol. 2012;5(2):560-7. doi: https://doi.org/10.1007/s11947-009-0312-x

24. Sandoval-Castilla O, Lobato-Calleros C, Aguirre-Mandujano E, Vernon-Carter EJ. Microstructure and texture of yogurt as influenced by fat replacers. Int Dairy J. 2004;14(2):151-9. doi: https://doi.org/10.1016/S0958-6946(03)00166-3

25. Yuliarti O, Mei KH, Kam Xue Ting Z, Yi KY. Influence of combination carboxymethylcellulose and pectin on the stability of acidified milk drinks. Food Hydrocoll. 2019;89:216-23. doi: https://doi. org/10.1016/j.foodhyd.2018.10.040

26. Tuinier R, Rolin C, de Kruif CG. Electrosorption of Pectin onto Casein Micelles. Biomacromolecules. 2002;3(3):632-8. doi: https:// doi.org/10.1021/bm025530x

27. Schmidt KA, Smith DE. Milk Reactivity of Gum and Milk Protein Solutions1. J Dairy Sci. 1992;75(12):3290-5. doi: https://doi. org/10.3168/jds.S0022-0302(92)78104-1

28. Nguyen PTM, Kravchuk O, Bhandari B, Prakash S. Effect of different hydrocolloids on texture, rheology, tribology and sensory perception of texture and mouthfeel of low-fat pot-set yoghurt. Food Hydrocoll. 2017;72:90-104. doi: https://doi.org/10.1016/j. foodhyd.2017.05.035

29. Sanz T, Salvador A, Jiménez A, Fiszman SM. Yogurt enrichment with functional asparagus fibre. Effect of fibre extraction method on rheological properties, colour, and sensory acceptance. Eur Food Res Technol. 2008;227(5):1515-21. doi: https://doi. org/10.1007/s00217-008-0874-2

30. Nan C, Dong X. Towards a maximal cell survival in convective thermal drying processes. Food Res Int. 2011;44:1127-49. https:// doi.org/10.1016/j.foodres.2011.03.053

31. Morales FJ, van Boekel MAJS. A Study on Advanced Maillard Reaction in Heated Casein/Sugar Solutions: Colour Formation. Int Dairy J. 1998;8(10):907-15. doi: https://doi.org/10.1016/S09586946(99)00014-X

32. Izadi M, Eskandari MH, Niakousari M, Shekarforoush S, Hanifpour MA, Izadi Z. Optimisation of a pilot-scale spray drying process 
for probiotic yoghurt, using response surface methodology. Int J Dairy Technol. 2014;67(2):211-9. doi: https://doi.org/10.1111/1471 0307.12108

33. Erbay Z, Koca N, Kaymak-Ertekin F, Ucuncu M. Optimization of spray drying process in cheese powder production. Food
Bioprod Process. 2015;93:156-65. doi: https://doi.org/10.1016/j. fbp.2013.12.008

34. Tontul I, Ergin F, Eroğlu E, Küçükçetin A, Topuz A. Physical and microbiological properties of yoghurt powder produced by refractance window drying. Int Dairy J. 2018;85:169-76. doi: https://doi.org/10.1016/j.idairyj.2018.06.002 